\title{
Corporate entrepreneurship and sustainability transitions: resource redeployment of oil and gas industry firms in floating wind power
}

\author{
Tuukka Mäkitie \\ trmakiti@tik.uio.no \\ TIK Center for Technology, Innovation and Culture, University of Oslo, Norway \\ Published in Technology Analysis \& Strategic Management \\ POST-PRINT \\ https://doi.org/10.1080/09537325.2019.1668553
}

\begin{abstract}
It has been recently argued that the vast resources of established firms can potentially accelerate sustainability transitions. This paper contributes to the study of such possibilities by investigating the resource redeployment of three Norwegian oil and gas industry firms in corporate ventures in floating wind power technologies. Using interview and document data, the findings show that the opportunity to use existing firm resources was a key motivation for established firms to engage in entrepreneurship in such technologies. The firms could redeploy their specialized and general-purpose resources in these entrepreneurial ventures, and develop new technologies on the basis of their existing resources. However, also challenges and controversies were observed. This paper thus suggests that the process of resource redeployment can help to explain why, and describe how, established firms may engage in cleantech innovation through corporate entrepreneurship.
\end{abstract}

\section{Keywords}

Corporate entrepreneurship; Floating wind power; Oil and gas industry; Sustainability transitions 


\section{Introduction}

Established firms in the energy sector, for instance those responsible of the production of oil and gas $(O \& G)$, are often considered to be passive or to resist sustainability transitions (Newell and Paterson, 1998, Geels, 2014). This is because they have vested interests in the current energy system, and their competences may be focused on the routines and capabilities related to the extraction of hydrocarbons (Nelson and Winter, 1982, Hess, 2014). Thus, clean technologies, such as renewable energy technologies, are often expected to be developed by smaller start-up firms (Hockerts and Wüstenhagen, 2010).

Nevertheless, recent studies have reported that established companies can also play an important role in the development of new cleantech (Berggren et al., 2015, Wesseling et al., 2015, Apajalahti et al., 2018). As argued by Frank Geels, "incumbent actors can resist, delay or derail low-carbon transitions, but they can also accelerate them if they reorient their strategies and resources towards niche-innovations" (Geels, 2018). However, such engagement of established firms in cleantech innovations remains little studied in sustainability transitions research.

First, despite the above mentioned potential of established firms' resources to accelerate transitions, few studies have elaborated on why, and how, established firms may redeploy their resources to cleantech (Wesseling et al., 2015, Hansen and Coenen, 2017). This highlights the need in sustainability transition research to better understand the process of resource redeployment of established firms, as well as the kinds of resources that may be redeployed. Analysis of resource redeployment may also reveal possible challenges in such processes, providing useful insights for both policy-makers and managers.

Second, even though entrepreneurial experimentation is widely recognized as a key process in cleantech innovation (Hekkert et al., 2007, Bergek et al., 2008), the corporate entrepreneurship of established firms has been little discussed in the context of sustainability transitions. Further analysis of established firms' engagement in such activities is useful for a better understanding of how they may contribute to sustainability transitions.

I will address these research gaps in sustainability transitions literature by drawing on the literature on corporate entrepreneurship and resource-based view of a firm in management studies, and by performing a multiple case study. The purpose of this exercise is to inform sustainability transition studies of why, and how, established firms may engage in innovation in radical clean technologies, and redeploy their resources in entrepreneurial activities.

I studied three Norwegian O\&G industry firms' corporate entrepreneurship in floating wind power (FWP) technologies. This topic presents an illustrative example of resource redeployment between two technologically related industries (Hansen and Steen, 2015). FWP, for its part, has the potential of making an important contribution to the sustainability 
transition in the energy sector. FWP is still in its early phase with only a few demonstration projects worldwide, but it is expected to show a steeper rate of cost reduction over time than the traditional bottom-fixed offshore wind power (OWP), thus possibly becoming the most cost-efficient means of producing OWP by 2030 (IEA, 2018).

My findings suggest that the redeployment of existing firm resources was a key process in corporate entrepreneurship in FWP for the studied firms. First, the opportunities for resource redeployment acted as an important motivation. Second, the established firms had used their specialized technological resources and organizational general-purpose resources in entrepreneurial ventures. However, managers in the studied companies had to deal with various challenges, such as the controversy of redeploying resources to the yet emerging FWP market rather than to the currently profitable O\&G market. Third, the firms had used their existing resources in developing new-to-the-world FWP technologies.

In section 2, I elaborate on the theoretical foundations of this paper, while section 3 explains the methodology. Section 4 presents the empirical findings, and section 5 discusses these results. Section 6 concludes.

\section{Theoretical perspectives}

\subsection{Established firms contributing to sustainability transitions}

It has recently been recognized that established firms may contribute to sustainability transitions (Geels, 2018, Köhler et al., 2019). This may take place for instance through their engagement in cleantech innovation, as the resources and the adopted strategies of established firms may feed into to the system-level innovation processes of technologies (Markard and Truffer, 2008). Wesseling and colleagues (2015) suggest that both incentives and opportunities are needed for established firms to engage in radical cleantech innovation (cf. van Mossel et al., 2018). Incentives may include exogenous pressures, such as the climate change debate and the destabilization of current markets (Karltorp and Sandén, 2012, Penna and Geels, 2015). Moreover, expectations of market opportunities may attract established firms to engage in innovation in radical cleantech (Budde et al., 2012, Bakker, 2014, Apajalahti et al., 2018). On the other hand, the accumulated resources may provide an opportunity for the established firms to use them in cleantech innovation (Bergek et al., 2013, Berggren et al., 2015, Steen and Weaver, 2017).

However, the processes of resource redeployment and corporate entrepreneurship have not yet been subjected to a detailed analysis in this literature. Therefore, I draw on the literatures on corporate entrepreneurship and resource-based view of a firm in management studies to inform my analysis on these topics. 


\subsection{Corporate entrepreneurship}

Corporate entrepreneurship is understood in this paper as a process of an established company engaging in innovation in a new market (Sharma and Chrisman, 1999). Corporate entrepreneurship may therefore provide an opportunity for established firms to pursue radical innovation alongside the more incremental development in their existing businesses (Tushman and O'Reilly, 1996). Firms may engage in corporate entrepreneurship e.g. to improve their performance amidst changing environmental conditions (Zahra and Covin, 1995), to achieve strategic renewal (Guth and Ginsberg, 1990), and to develop future revenue streams by reusing their existing firm resources (McGrath et al., 1994). This implies that corporate entrepreneurship may also raise management dilemmas, e.g. whether the resources of the firm should be focused on short-term profitability and today's customers, or creating business opportunities for future and anticipating the customer preferences of tomorrow (Andriopoulos and Lewis, 2009).

Corporate entrepreneurship can take place through the creation of a new venture aiming at developing a new business through the commercialization of an innovative technology. Such ventures can be placed in a new organization, either internally in the existing company as e.g. a project or a division, or in a separate company (Sharma and Chrisman, 1999, Kuratko and Audretsch, 2013). Internal ventures may take the form of e.g. in-house development of a technology in a new market. External ventures can take place for instance through setting up a separate company for in-house technology development, or acquiring a start-up company with an innovative technology.

The decision to develop ventures in-house, rather than buying shares in an external company, can be motivated e.g. by the desire to have a stronger control over technology development (Bjørgum, 2016). For instance, an established firm may develop new technologies in their R\&D laboratories, and then seek to bring them to the marketplace (Buenstorf, 2016). In-house ventures therefore often utilize the existing resources of established firms, for instance human resources and technological and marketing expertise (Tidd and Taurins, 1999).

Acquisition of a technology start-up can be a faster way to develop a new business, and provide flexibility for established firms in comparison to the more arduous in-house development (Bjørgum, 2016). Acquired firms often have a complementary knowledge space with the established firms. For instance, smaller companies may have advantages in developing disruptive technologies, while larger firms may possess resources that are useful in commercialization (Maula et al., 2005, Andersson and Xiao, 2016). For instance, by using their larger resource base and experience, the established firms can often support start-up firms in their R\&D efforts, and use their existing firm resources in legitimizing and scaling up new technologies (Bjørgum and Sørheim, 2015, Lindholm-Dahlstrand et al., 2018). Access to such complementary resources through (the often patient) ownership of established firms can 
be particularly helpful in developing new-to-the-world technologies, as it may otherwise be difficult to obtain such assets externally due to the high uncertainty inherent for such technologies (Park and Steensma, 2012, Bjørgum and Sørheim, 2015).

To summarize, corporate entrepreneurship typically draws on the existing resources of established firms (Narayanan et al., 2009). Using existing firm resources in new markets, i.e. resource redeployment, is therefore a key process (Guth and Ginsberg, 1990).

\subsection{Resource redeployment}

Firm resources refer to all assets, organizational processes, knowledge, facilities etc. possessed by the firm. The resource-based view of a firm argues that resources have central importance for firms' growth and ability to compete in the marketplace (Penrose, 1959, Barney, 1991). Growth can take place particularly through the use of existing resources in related markets (Helfat and Lieberman, 2002). Resource redeployment is therefore often considered a key process determining in which markets established firms choose to enter (Sakhartov and Folta, 2015, Lieberman et al., 2017). The key notion in resource redeployment is that some firm resources are fungible, meaning that the resources are not only confined to their current use, but can also be applied in other markets (Teece, 1982, Anand and Singh, 1997). Fungibility of resources can be seen as a continuum between specialized and generalpurpose resources, where former are limited to only few markets, while latter ones are applicable in several markets (Helfat and Lieberman, 2002, Pisano, 2017).

Redeployment of existing firm resources alone is unlikely to be enough for building a successful new business, and therefore development of new specialized resources is also needed (Pisano, 2017). Nevertheless, resource redeployment can take place also in the development of new resources (Kaul, 2012). For instance when developing new specialized knowledge or technologies, the existing R\&D capacity and capabilities of firms is often used. Moreover, managerial attention and financial resources are needed, also when acquiring the resources externally, e.g. through acquisitions or contracting. The resource redeployment in development of new resources is illustrated through the opportunity cost that is associated in such investments. In other words, development of new resources may disallow the use of the same R\&D capacity, managerial attention or financial investment in the core market of the firm (Levinthal and Wu, 2010).

Different authors have categorized the content of firm resources in different ways (see e.g. Helfat and Lieberman, 2002, Tanriverdi and Venkatraman, 2005). As the interest of this paper is particularly on technology development, technological resources are highlighted, consisting particularly of the knowledge regarding technologies. Firms commonly utilize their existing technological resources when developing and learning about new technologies, and firms 
tend to enter markets where they can use their existing technological resources (Granstrand, 1998, Breschi et al., 2003). Organizational resources consist of e.g. managerial capabilities (Tanriverdi and Venkatraman, 2005), product design and manufacturing capabilities (Magnusson et al., 2005) and human and financial assets (Chatterjee and Wernerfelt, 1991, Farjoun, 1994). Moreover, organizational resources may refer to institutions such as the established practices and the identities of the company (Balmer and Greyser, 2002, Melewar et al., 2005). The possibility to redeploy both technological and organizational resources can be crucial in whether established firms will engage in developing new technologies (Magnusson et al., 2005).

\section{Methodology}

I performed a qualitative multiple case study of three companies. The empirical analysis had three phases.

First, all Norwegian O\&G operator and supplier companies, who had engaged in developing and commercializing FWP technologies, were identified. Seven companies were contacted, while three agreed to take part in the study (see Table 1). Following the European Commission's definition, two of the companies were large and one was medium-sized. Two of the companies had developed a new FWP technology in-house, while the remaining one had acquired a share in a start-up company with a novel FWP concept. All technological concepts put emphasis on the foundation structure, and were not seeking to develop e.g. new types of generators or blades. Hence, the challenges and opportunities faced by the companies were similar in all cases, making them comparable.

Table 1 The case study companies

\begin{tabular}{|l|l|}
\hline Name & Type of company and corporate entrepreneurship \\
\hline Firm 1 & A large company, an in-house technology development \\
\hline Firm 2 & A medium-sized company, an in-house technology development \\
\hline Firm 3 & A large company, purchase of shares in an external FWP venture \\
\hline
\end{tabular}

Second, semi-structured interviews with the companies were performed in two rounds and used as the main source of data (see Appendix for the list of interviews). The first round of interviews took place during April-September 2018. A total of seven interviews with senior managers in the case study companies were made. Moreover, five industry experts, selected for their high level of knowledge of the Norwegian O\&G industry and its activities in OWP, were interviewed. All interviews lasted approximately an hour, were recorded, conducted in English in person, by phone or audio/video connection, and fully transcribed into written format. The used quotes in this paper are therefore presented verbatim. In the second round 
of interviews in January-February 2019, a draft version of this research paper was sent to the key respondents in the case study companies prior to the meetings. Then the preliminary findings of this paper were presented, providing an opportunity to discuss the results, to correct any prior misunderstandings, and to gather additional data. These second round meetings lasted an hour, were not recorded, but extensive meeting notes were gathered instead.

I further collected and analyzed document data, such as annual reports, firm websites and other available documents. Patents available in the Espacenet service of the European Patent Office were also gathered. The search terms were "wind" in title and abstract, and the company names as applicants. Non-OWP related patents were discarded, concluding with 23 patents. The citations made in these patents (in all available country versions, removing duplicate citations) to other patents were collected. By reading through the abstracts, it was determined if the cited patent was describing a technology mainly intended for wind power production, O\&G or other markets.

Third, the data was analyzed with the help of the NVivo software. The initial part of coding identified the motivations and firm resources involved in corporate entrepreneurship. Next, the redeployed resources were categorized by the degree of specialization: specialized resources (mainly applicable in offshore markets), general-purpose resources (i.e. resources applicable in multiple markets) or new resources (i.e. resources developed for FWP) (Pisano, 2017). They were also coded in terms of their content (technological and organizational resources) (Magnusson et al., 2005).

\section{Results}

\subsection{Floating wind power technologies}

OWP turbines, this far mostly implemented by fixing them to the sea bottom, is a capitalintensive technology which is beginning to mature as a cost-competitive renewable energy technology (see Figure 1). However, bottom-fixed OWP is limited to water depths of maximum 40-60 meters and e.g. to suitable sea-bottom conditions. Hence, to disseminate OWP to more geographic locations in the world, for example the deep shores of Japan and the Western North America, FWP technologies are required. 


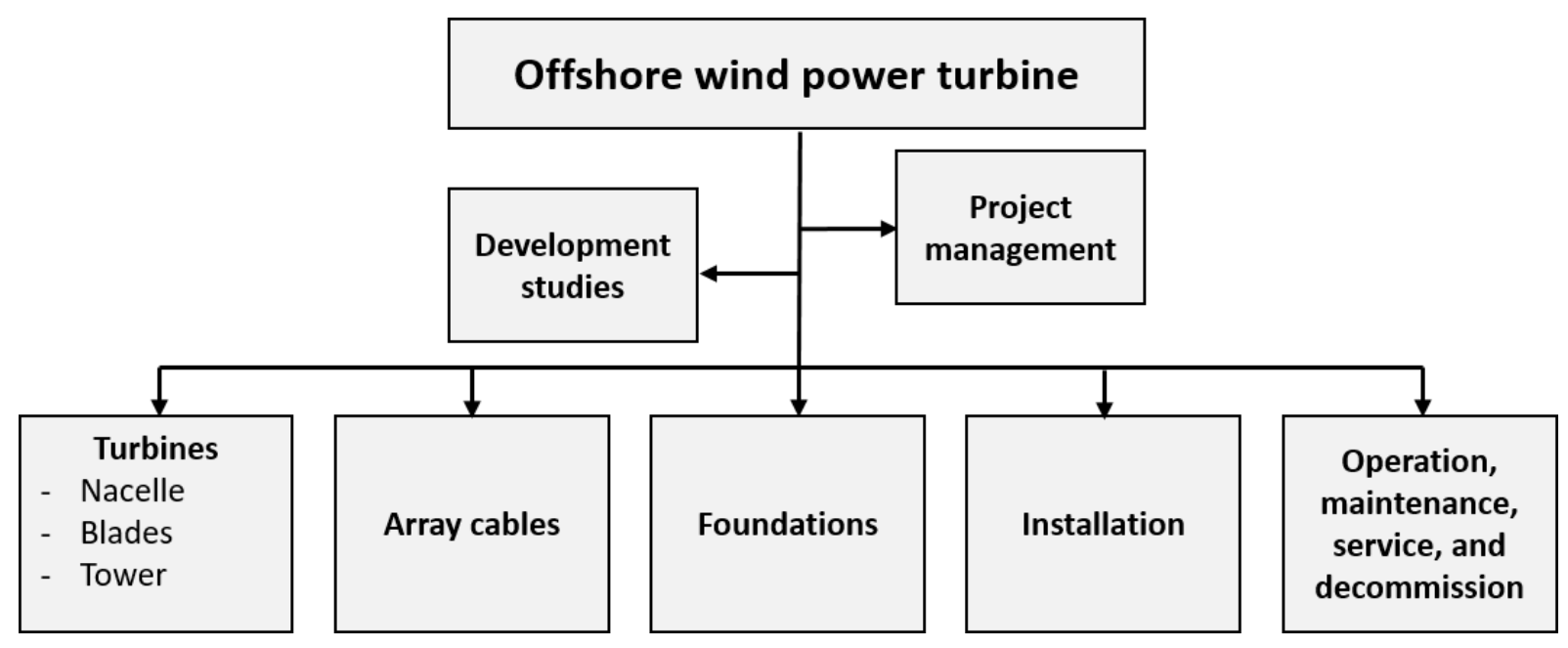

Figure 1 The system breakdown of OWP turbines (adapted from NORWEP, 2017).

Floating technologies, such as buoyant semi-submersible constructions, cylindrical up-right floating spar buoys, and tension-leg platforms standing on "stiff" vertical moorings, are novel to the wind power sector, but well-known in the offshore O\&G industry. Due to this technological relatedness, FWP has been seen as a market opportunity in the O\&G industry, and several O\&G industry companies, especially in Norway, have engaged in FWP development (cf. Mäkitie et al., 2018a, 2019). It therefore presents an illustrative context to study where established firms have used their existing resources in technology development and corporate entrepreneurship in a new cleantech.

\subsection{The motivations of firms to pursue corporate entrepreneurship in FWP}

Two key factors had motivated the studied firms to engage in FWP ventures: the perceived transition in the energy sector, and the opportunity to redeploy existing firm resources.

First, especially in Europe, renewable energy production has grown rapidly in recent decades, with a clear trend of public ambitions to increase its share in the electricity mix.

"We saw quite clearly [--] that we are going to have the energy market in a huge transition. We will try to be in the forefront, so we will try to move early. (1)

Pressure to do so is particularly relevant for O\&G industry firms, which in the long term may end up being locked into the declining and "undesirable" side of the energy market. This caused pressures for entry in renewable energy, which was also seen as an increasingly attractive market opportunity. However, all companies remained committed in continued operations also in the O\&G market.

"[Some of] our clients [--] have divested their O\&G business. So the question is if oil will be over time the new tobacco. This is not what I think, but there are people saying that. [--] So there is a fundamental change in the business. And for the first time we are seeing 
that [--] renewables is certainly picking up and becoming a reliable source of energy." (7a)

For Firm 1, the entry to renewable energy was a strategic goal in and of itself. Entrepreneurship in FWP therefore possessed also a symbolic meaning in showing to the public that they also have a sustainable energy business.

Second, the opportunities to redeploy existing firm resources played a central role in why the firms had engaged in FWP ventures. The firms could utilize their existing knowledge, thus developing FWP technologies based on known and proven O\&G technologies and techniques (see also section 4.3.3). Especially the in-house technology developers saw an opportunity in leveraging their existing engineering competences. Firm 3 noticed the same opportunity, but decided upon another approach.

"We actually developed a design ourselves which is based on our technology in floating O\&G. We quickly realized that the clients were after proven concepts. [--] Coming from analysis model and drawings into a tank test and building a prototype, it would take us years. [--] So we went out on to the market and quickly understood that the best fit with our technology was [the acquired company]. So, we invested in [the acquired company]." (7a)

In the large Firm 1, the logic of resource redeployment was also used inside the organization to convince the top management to allocate resources for the project. Resource redeployment was seen to reduce the uncertainty, cost and time involved in the technology development, thus making the project more attractive for the top management.

"We were looking into a quite a set of different ideas and concepts but found that should we be able to promote this idea, it has to be built upon known technologies. Many people had proposed a lot of wind turbine ideas, which combine a lot of new technologies that have to be developed. Who would put the money into that? [--] [Using existing technologies] was, I think, an important selling argument." (12)

In the following section, I analyze such redeployed resources in more detail.

\subsection{Resource redeployment in corporate entrepreneurship}

\subsubsection{Existing specialized resources}

\section{Technological resources}

The existing knowledge regarding floating offshore foundations was a central redeployed resource in all firms. Albeit transferring floating technologies from O\&G to OWP required 
some changes e.g. in the size and the design of the structures, the companies were confident of their ability to adapt.

"To optimize the design of these structures in the marine environment, those are the same things we do when we optimize a floating [O\&G] structure or a platform structure."

Another important redeployed technology was the moorings, i.e. the anchorage and chains attaching the floating device to the sea-bottom. Similarly, two companies could use their O\&G experiences in power cabling and equipment, which in the $O \& G$ are used in e.g. subsea technologies, i.e. technologies operated at the sea-bottom, and powering platform equipment. The companies also had knowledge regarding suitable offshore materials, such as steel and concrete, used in offshore constructions. Besides mitigating corrosion caused by the saline sea water, this was important to minimize the costs of foundations and enabling problem-free fabrication.

\section{Organizational resources}

Over the years of business activities in the offshore O\&G market, the companies had developed an offshore identity which was visible in their willingness to engage in entrepreneurship in FWP. For example in Firm 2, while the market opportunity also played a role, this inherent interest in offshore technologies was described as a key factor for their commitment in their venture.

"We are sort of nerds here (laughs) so we see what we know and what we are interested in developing from technological perspective." (4a)

\section{Summary}

Table 2 summarizes the above insights. Particularly the specialized resources in marine technologies (such as floating foundations and mooring) proved important for the firms in their corporate entrepreneurship in FWP.

Table 2 The redeployed specialized resources. Light grey color: redeployment took place. Dark grey: no redeployment.

\begin{tabular}{|l|l|l|l|l|}
\hline & Specialized offshore resources & Firm 1 & Firm 2 & Firm 3 \\
\hline \multirow{3}{*}{ Technological } & Floating offshore foundations & & & \\
\cline { 2 - 5 } & Mooring & & & \\
\cline { 2 - 5 } & Power cabling and electrical equipment & & & \\
\cline { 2 - 5 } & Offshore materials & & & \\
\hline Organizational & Offshore identity & & \\
\hline
\end{tabular}




\subsubsection{Existing general-purpose resources}

\section{Technological resources}

The large Firms 1 and 3 had employed their broad technical capabilities. Such competences included e.g. meteorology, logistics and environmental impact assessment. In addition, they had also redeployed their experience in integration of technologies into a single complex system.

"We know how to design the details of those components and analyze the dynamic system in one piece. So this [--] dynamic analysis, we are quite strong in that." (8a)

Such system integration of technologies is an important feature in complex constructions, such as floating O\&G platforms. While OWP turbines are somewhat "simpler", it is nevertheless important to understand how the different components (e.g. the foundation, the generator, and blades) affect each other in a challenging (and moving) natural environment characterized by strong winds, currents and waves.

\section{Organizational resources}

All firms had utilized their R\&D and engineering capacity in developing a new technological concept. In the acquirer Firm 3, the start-up company was primarily responsible of the R\&D, but Firm 3 itself could nevertheless give support in specific engineering challenges.

"[They] can't afford to have a big materials school for example. [--] We probably have more material engineers than they have engineers." (8a)

In the in-house developer Firm 1, such redeployment of R\&D capacity from the highly profitable O\&G market to still much smaller OWP was not without managerial controversies.

"We have to compare pears and apples here. Because it has a hard strategic value to develop the next generation [OWP] technologies. But it also has a very high shorter value to optimize this [O\&G] production. So, it's a struggle." (1)

Offshore O\&G projects are usually custom-made, as the particular technical characteristics of different projects mean that technologies used in one field are rarely directly applicable in others. This means that companies continuously need to adapt and develop new technologies. In organizations accustomed to such activities, the FWP technologies were therefore seen as just another technology development project, allowing the companies to redeploy their usual R\&D processes. 
"[Our company] has been a pioneer in the O\&G, developing technologies. [--] [The FWP project], that's just a part of the technology development I have been part of over the years working for the O\&G industry." (2)

The two large companies could redeploy their existing capabilities to managing large projects, which was seen important when the technologies were advancing towards demonstration projects.

"The R\&D took this concept to a certain level, and when it was decided to build it, [the $R \& D$ department] was out of the project and there was a professional project execution team that was used to build big platforms and do big projects and could do this professionally with contracts, with timing, and budgeting." (12)

Supply chain management was seen as a key redeployed competence when seeking to bring the FWP turbines closer to commercialization. Such processes in OWP were perceived similar to the O\&G.

"If we are going to produce thousands and thousands of tons of steel on global basis, that's where [our company] has a rock-solid background [---]. This is sort of the value that [our company] brings to the table: the solid long-term competence in technical solutions, global operations and project execution down to commission." (8b)

Firms had delivered in-house financing to ventures by redeploying financial and human capital. The medium-sized Firm 2, however, was particularly struggling when the venture was moving towards the more costly demonstration phase.

"We don't have the muscles to do that or the financing, so that's what we are struggling with these days." (4a)

Firm 3 had helped their start-up company with similar issues by providing financial strength and credibility, as well as international presence through their multi-national organization, to the venture.

"Although [the acquired company] has a fantastic technology, they are a great company, they are only [less than 50] people. So they need the balance sheet and the credibility of a big organization. So that's what [our company] is providing in that ownership." (7a)

\section{Summary}

Table 3 summarizes the above findings. The organizational resources, such as those related to R\&D and management competences, played an important role. Especially the large Firms 1 
and 3 could leverage many more general-purpose resources in comparison to the smaller Firm 2 , for example their financial strength and large-scale project management competences.

Table 3 Redeployed general-purpose resources

\begin{tabular}{|l|l|l|l|l|}
\hline & General-purpose resources & Firm 1 & Firm 2 & Firm 3 \\
\hline Technological & Broad technical capabilities & & & \\
\cline { 2 - 5 } & Integration of technologies & & & \\
\hline \multirow{5}{*}{ Organizational } & R\&D and engineering capacity & & & \\
\cline { 2 - 5 } & Established R\&D processes & & & \\
\cline { 2 - 5 } & Management of large projects and supply chains & & & \\
\cline { 2 - 5 } & In-house financing & & & \\
\cline { 2 - 5 } & Financial strength and credibility & & \\
\hline
\end{tabular}

\subsubsection{Development of new firm resources}

\section{Technological resources}

All companies had engaged in creating new specialized OWP technologies. Especially the inhouse technology developers Firms 1 and 2 were heavily engaged with a total of 23 found patents for their OWP technologies. In terms of the citations of these patents, three quarters referred to wind power technologies, while O\&G related citations were few (see Figure 2). This difference in citations may reflect different patenting practices between the two industries. However, the large number of patents and wind power citations show that the companies had developed an extensive knowledge base in specialized OWP technologies.

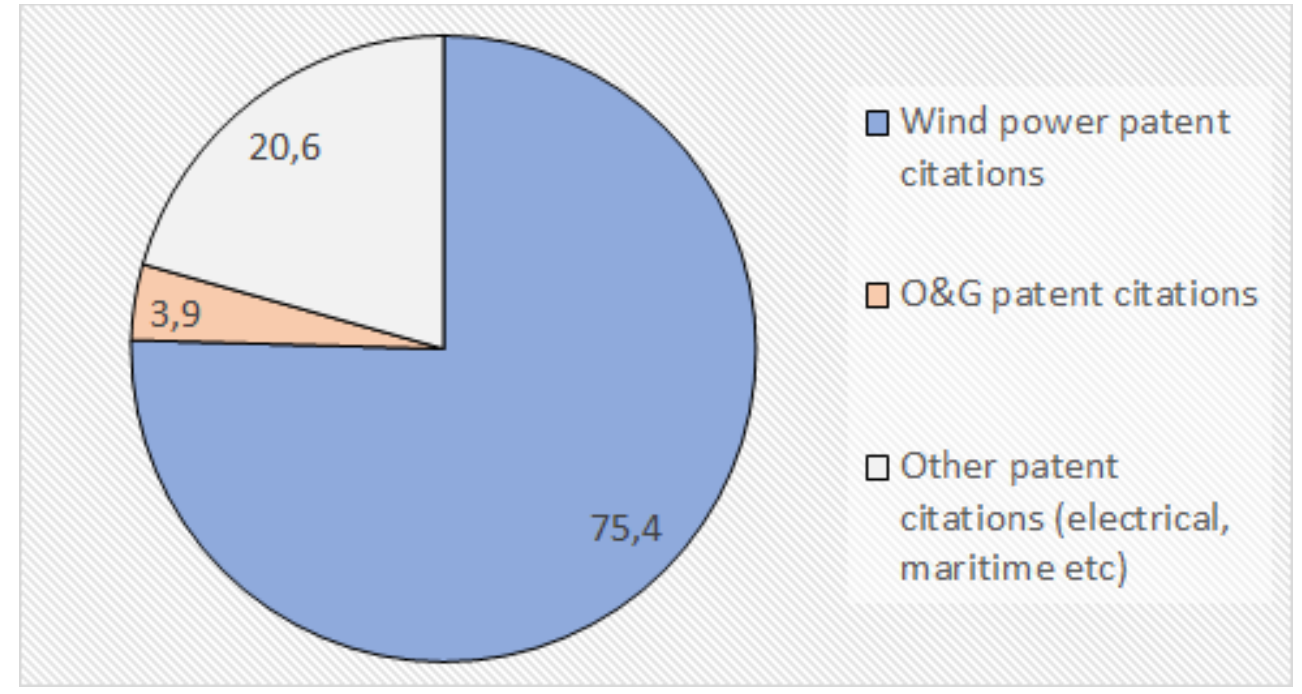

Figure 2 The OWP patent citations to other patents (per cents, 281 citations in total).

However, the new OWP technologies were still described to be based on their existing O\&G knowledge.

"The whole idea was to [--] directly use what we had done in O\&G industry before. [--] 
We have a known floating concept, we are using a known wind turbine concept, we are using a known mooring concept. So, there is nothing new. We know all the components, but we put them together in a different way and use it for a different purpose." (12)

OWP turbines nevertheless differ from O\&G platforms, which posed needs for completely new technologies. In Firm 1, controller systems of turbines were considered important.

"So that's the real own technology development that we have." (2)

Such controllers minimize the movement of the turbine, and reduce its fatigue in the harsh open sea conditions, thus extending its lifetime to at least 20 years. Even though these were new technologies, the company could nevertheless lean back to their engineering competences developed in the O\&G industry in solving similar kinds of technical challenges.

"We do understand how these interacted systems work together and how the forces from the wind, from the waves, from the tides, from the currents, how all these forces come together and suppress the system and how it can be designed to move as little as possible. So all these things are transferred directly [from O\&G]." (1)

\section{Organizational resources}

The companies had also developed new stakeholders and supplier relationships. Especially the relationships with wind turbine manufacturers proved to be challenging to establish, as they were described reluctant to explore FWP technologies.

"We wanted to put a standard turbine on top of this [floating structure]. [The turbine manufacturers] were very skeptical, because they had never seen a turbine which was put on a device that could move." (12)

Establishing relationships with large turbine manufacturers was particularly challenging for the medium-sized Firm 2.

"It's crucial for succeeding in this market to have good relations with [large turbine manufacturers], which is quite difficult actually if you are a small player. They don't want to listen to you and especially they haven't been too interested in the floating wind." (6a)

Another key challenge was the importance of cost-efficiency in OWP.

"The cost is the difficult part (laughs). We can make anything [in OWP] if the cost was not a concern." (8a)

This has to do with the different requirements for the O\&G and OWP technologies. In an O\&G 
platform, people work close to high-pressurized and explosive materials, where technological malfunctions may lead to loss of life, major environmental pollution and gigantic financial losses. Quality and safety of technologies are therefore priorities. In comparison, the reduction of cost in mass-produced turbines is a key imperative in the OWP market to make it price-competitive against other forms of electricity production. Moreover, safety is less critical as turbines operate without personnel. For the studied companies, this meant the development of a cost-efficiency mindset.

"We have to overcome our tendency to tweak everything to perfection. Because [in O\&G] you don't take chances. [--] But in wind we have to sort of tweak it to the right level, which is good enough, and then leave it. And this I think will be a mental challenge for our technology teams." (8b)

Moreover, while being established players in the O\&G market, especially the large companies found themselves now as new-comers in the OWP market. However, such new status in the market was welcomed with a positive response from the side of the employees.

"We had an advert out for a leader of the wind team. And there were more than 50 applications. Internal only. A few years ago we were all skeptical towards renewables. [-] [Now] everyone wants to join the team." (7a)

This reflects a perceived on-going transition in the energy industry, attracting O\&G employees to apply their competences in renewable energy technologies.

\section{Summary}

Corporate entrepreneurship in FWP required developing new resources (Table 4). The firms could nevertheless use their existing technological resources in developing new specialized OWP technologies. Meanwhile, they also had to develop completely new organizational resources, such as a cost-efficiency mindset.

Table 4 Development of new firm resources

\begin{tabular}{|l|l|l|l|l|}
\hline & New firm resources & Firm 1 & Firm 2 & Firm 3 \\
\hline Technological & Specialized OWP technologies & & & \\
\hline \multirow{3}{*}{ Organizational } & New customer and supplier relationships & & & \\
\cline { 2 - 5 } & Cost-efficiency mindset & & & \\
\cline { 2 - 5 } & New status in the market & & & \\
\hline
\end{tabular}




\section{Discussion}

In this paper I investigated why, and how, established O\&G industry firms had engaged in FWP technologies and the process of resource redeployment in entrepreneurial activities. Three main findings emerged.

First, while the perception of an on-going energy transition was an important motivation, the opportunity for resource redeployment was a key factor why the firms had engaged in corporate entrepreneurship in FWP (cf. Wesseling et al., 2015). The firms could utilize their existing $O \& G$ resources in in-house ventures and external acquisitions, and thus achieve a competitive advantage in the possible future market for these technologies. Hence, the perceived opportunity of resource redeployment was a key explanation for why the established firms engaged in corporate entrepreneurship (Helfat and Lieberman, 2002, Narayanan et al., 2009). In other words, results of this paper support e.g. Karltorp and Sandén (2012) and Wesseling and colleagues (2015) in arguing that in addition to the expectations of market opportunities and decline (e.g. Budde et al., 2012), the opportunities to redeploy existing resources may help to explain why established firms take part in sustainability transitions (van Mossel et al., 2018).

Second, both the existing specialized and the general-purpose resources of the firms were redeployed in entrepreneurial ventures (McGrath et al., 1994, Pisano, 2017). While the specialized offshore technology resources were particularly important in in-house ventures, the large firms could also utilize their general-purpose organizational resources, especially their financial strength and managerial capabilities. The resource redeployment was nevertheless not without its difficulties. For instance in Firm 1, the resource redeployment to FWP was reported to be in conflict with concentrating the resources to the current O\&G market (cf. Tushman and O'Reilly, 1996, Andriopoulos and Lewis, 2009). For managers and policy-makers, such controversies underline the importance of long-term commitment in corporate ventures backed by the company strategy and the support from the top management of the company. Otherwise, it may become tempting to pull back the redeployed resources e.g. if the new cleantech market experiences slow progress, and the core market experiences renewed growth (Lieberman et al., 2017, Mäkitie et al., 2018b, Mäkitie et al., 2019).

Third, resource redeployment also took place when the firms developed new specialized FWP resources. Even though the patent citations suggested otherwise, the new technologies were described to be based on the existing O\&G experience and knowledge of the companies. In other words, while the ventures required creation of new technological knowledge, this process could nevertheless utilize the existing resources of the firms, for example the engineering competences of the employees (Kaul, 2012). The firms, however, were challenged by the need to also develop new organizational resources, such as the mindset of costefficiency, to succeed in FWP. For managers and policy-makers this shows that the challenge 
faced by the established firms should not only be seen in terms of developing new technological knowledge, but also in terms of e.g. new institutions and mindsets that may have to be adopted.

\section{Conclusion}

This paper has studied the topics of established firms' corporate entrepreneurship and resource redeployment in clean technologies. The analysis has provided insights on the established firms' motivations and processes in such activities. Moreover, the paper has specified the types of resources (market-specific vs. general-purpose resources, technological vs. organizational resources) that established firms may redeploy in the development of cleantech. The paper has thus contributed to the emerging literature regarding established firms in sustainability transitions (e.g. Budde et al., 2012, Wesseling et al., 2015, Steen and Weaver, 2017, van Mossel et al., 2018) by showing the importance of resource redeployment both as a key motivation and a key process explaining why, and how, established firms may engage in cleantech innovation. In other words, the opportunities and the processes of resource redeployment therefore may help to explain how established firms may contribute to accelerating sustainability transitions.

This paper nevertheless has limitations, which also open up opportunities for further research. First, the paper remained limited in assessing the implications of corporate entrepreneurship and associated resource redeployment for the system-level innovation around FWP (Bergek et al., 2008, Markard and Truffer, 2008). Thus the assessment of the impact of O\&G firms on FWP innovation is left for future studies. Second, my study was limited to a single national and technological context. Further studies would need to expand the scope other industries and countries. Finally, the interviews pointed to the possibly different roles that O\&G industry firms and OWP turbine manufacturers have played in the development in FWP. Interestingly, it seemed like that the O\&G industry firms had provided the entrepreneurial agency in FWP technologies, while the established wind power industry firms were described to resemble typical 'regime-like' firms, being passive and reluctant in radical innovation like FWP. A comparative study between O\&G and OWP firms in FWP technologies would be needed to confirm these findings.

\section{Acknowledgements}

This work was supported by the Research Council of Norway (grant number 237677). I thank the two anonymous reviewers for their constructive feedback. I would also like to thank Anna Bergek, Roger Sørheim and Taran Thune for their comments on the previous versions of this 
paper. Moreover, I would like to thank Taran Thune, Håkon Normann and Jens Hanson for the collaboration when organizing the interviews, and the interviewees for their insights and interesting discussions on the study topic.

\section{References}

ANAND, J. \& SINGH, H. 1997. Asset redeployment, acquisitions and corporate strategy in declining industries. Strategic Management Journal, 18, 99-118.

ANDERSSON, M. \& XIAO, J. 2016. Acquisitions of start-ups by incumbent businesses: A market selection process of "high-quality" entrants? Research Policy, 45, 272-290.

ANDRIOPOULOS, C. \& LEWIS, M. W. 2009. Exploitation-Exploration Tensions and Organizational Ambidexterity: Managing Paradoxes of Innovation. Organization Science, 20, 696-717.

APAJALAHTI, E.-L., TEMMES, A. \& LEMPIÄLÄ, T. 2018. Incumbent organisations shaping emerging technological fields: cases of solar photovoltaic and electric vehicle charging. Technology Analysis \& Strategic Management, 30, 44-57.

BAKKER, S. 2014. Actor rationales in sustainability transitions - Interests and expectations regarding electric vehicle recharging. Environmental Innovation and Societal Transitions, 13, 60-74.

BALMER, J. M. T. \& GREYSER, S. A. 2002. Managing the Multiple Identities of the Corporation. California Management Review, 44, 72-86.

BARNEY, J. 1991. Firm resources and sustained competitive advantage. Journal of Management, 17, 99-120.

BERGEK, A., BERGGREN, C., MAGNUSSON, T. \& HOBDAY, M. 2013. Technological discontinuities and the challenge for incumbent firms: Destruction, disruption or creative accumulation? Research Policy, 42, 1210-1224.

BERGEK, A., JACOBSSON, S., CARLSSON, B., LINDMARK, S. \& RICKNE, A. 2008. Analyzing the functional dynamics of technological innovation systems: A scheme of analysis. Research Policy, 37, 407-429.

BERGGREN, C., MAGNUSSON, T. \& SUSHANDOYO, D. 2015. Transition pathways revisited: Established firms as multi-level actors in the heavy vehicle industry. Research Policy, 44, 1017-1028.

BJ $\varnothing$ RGUM, $\varnothing$. 2016. MNCs entering an emerging industry: The choice of governance mode under high uncertainty. Cogent Business \& Management, 3.

BJ $\varnothing$ RGUM, $\varnothing . \& S \varnothing$ RHEIM, R. 2015. The funding of new technology firms in a precommercial industry - the role of smart capital. Technology Analysis \& Strategic Management, 27, 249-266.

BRESCHI, S., LISSONI, F. \& MALERBA, F. 2003. Knowledge-relatedness in firm technological diversification. Research Policy, 32, 69-87.

BUDDE, B., ALKEMADE, F. \& WEBER, K. M. 2012. Expectations as a key to understanding actor strategies in the field of fuel cell and hydrogen vehicles. Technological Forecasting and Social Change, 79, 1072-1083.

BUENSTORF, G. 2016. Schumpeterian incumbents and industry evolution. Journal of Evolutionary Economics, 26, 823-836.

CHATTERJEE, S. \& WERNERFELT, B. 1991. The link between resources and type of diversification: Theory and evidence. Strategic Management Journal, 12, 33-48. 
FARJOUN, M. 1994. Beyond Industry Boundaries: Human Expertise, Diversification and Resource-Related Industry Groups. Organization Science, 5, 185-199.

GEELS, F. W. 2014. Regime Resistance against Low-Carbon Transitions: Introducing Politics and Power into the Multi-Level Perspective. Theory, Culture \& Society, 31, 21-40.

GEELS, F. W. 2018. Disruption and low-carbon system transformation: Progress and new challenges in socio-technical transitions research and the Multi-Level Perspective. Energy Research \& Social Science, 37, 224-231.

GRANSTRAND, O. 1998. Towards a theory of the technology-based firm. Research Policy, 27, 465-489.

GUTH, W. D. \& GINSBERG, A. 1990. Guest Editors' Introduction: Corporate Entrepreneurship. Strategic Management Journal, 11, 5-15.

HANSEN, G. H. \& STEEN, M. 2015. Offshore oil and gas firms' involvement in offshore wind: Technological frames and undercurrents. Environmental Innovation and Societal Transitions, 17, 1-14.

HANSEN, T. \& COENEN, L. 2017. Unpacking resource mobilisation by incumbents for biorefineries: the role of micro-level factors for technological innovation system weaknesses. Technology Analysis \& Strategic Management, 29, 500-513.

HEKKERT, M. P., SUURS, R. A. A., NEGRO, S. O., KUHLMANN, S. \& SMITS, R. E. H. M. 2007. Functions of innovation systems: A new approach for analysing technological change. Technological Forecasting \& Social Change, 74, 413-432.

HELFAT, C. E. \& LIEBERMAN, M. B. 2002. The birth of capabilities: market entry and the importance of pre-history. Industrial and Corporate Change, 11, 725-760.

HESS, D. J. 2014. Sustainability transitions: A political coalition perspective. Research Policy, 43, 278-283.

HOCKERTS, K. \& WÜSTENHAGEN, R. 2010. Greening Goliaths versus emerging Davids Theorizing about the role of incumbents and new entrants in sustainable entrepreneurship. Journal of Business Venturing, 25, 481-492.

IEA 2018. Offshore Energy Outlook. International Energy Agency.

KARLTORP, K. \& SANDÉN, B. A. 2012. Explaining regime destabilisation in the pulp and paper industry. Environmental Innovation and Societal Transitions, 2, 66-81.

KAUL, A. 2012. Technology and Corporate Scope: Firm and Rival Innovation as Antecedents of Corporate Transactions. 33, 347-367.

KURATKO, D. F. \& AUDRETSCH, D. B. 2013. Clarifying the domains of corporate entrepreneurship. International Entrepreneurship and Management Jounal, 9, 323335.

KÖHLER, J., GEELS, F. W., KERN, F., MARKARD, J., ONSONGO, E., WIECZOREK, A., ALKEMADE, F., AVELINO, F., BERGEK, A., BOONS, F., FÜNFSCHILLING, L., HESS, D., HOLTZ, G., HYYSALO, S., JENKINS, K., KIVIMAA, P., MARTISKAINEN, M., MCMEEKIN, A., MÜHLEMEIER, M. S., NYKVIST, B., PEL, B., RAVEN, R., ROHRACHER, H., SANDÉN, B., SCHOT, J., SOVACOOL, B., TURNHEIM, B., WELCH, D. \& WELLS, P. 2019. An agenda for sustainability transitions research: State of the art and future directions. Environmental Innovation and Societal Transitions, 31, 1-32.

LEVINTHAL, D. A. \& WU, B. 2010. Opportunity costs and non-scale free capabilities: profit maximization, corporate scope, and profit margins. Strategic Management Journal, 31, 780-801.

LIEBERMAN, M. B., LEE, G. K. \& FOLTA, T. B. 2017. Entry, exit, and the potential for resource redeployment. Strategic Management Journal, 38, 526-544. 
LINDHOLM-DAHLSTRAND, Å., ANDERSSON, M. \& CARLSSON, B. 2018. Entrepreneurial experimentation: a key function in systems of innovation. Small Business Economics.

MAGNUSSON, T., TELL, F. \& WATSON, J. 2005. From CoPS to mass production? Capabilities and innovation in power generation equipment manufacturing. Industrial and Corporate Change, 14, 1-26.

MARKARD, J. \& TRUFFER, B. 2008. Actor-oriented analysis of innovation systems: exploring micro-meso level linkages in the case of stationary fuel cells. Technology Analysis \& Strategic Management, 20, 443-464.

MAULA, M., AUTIO, E. \& MURRAY, G. 2005. Corporate Venture Capitalists and Independent Venture Capitalists: What do they know, Who do They Know and Should Entrepreneurs Care? Venture Capital, 7, 3-21.

MCGRATH, R. G., VENKATARAMAN, S. \& MACMILLAN, I. C. 1994. The advantage chain: Antecedents to rents from internal corporate ventures. Journal of Business Venturing, 9, 351-369.

MELEWAR, T. C., KARAOSMANOGLU, E. \& PATERSON, D. 2005. Corporate identity: concept, components and contribution. Journal of General Management, 31, 59-81.

MÄKITIE, T., ANDERSEN, A. D., HANSON, J., NORMANN, H. E. \& THUNE, T. M. 2018 a. Established sectors expediting clean technology industries? The Norwegian oil and gas sector's influence on offshore wind power. Journal of Cleaner Production, 177, 813-823.

MÄKITIE, T., NORMANN, H. E., THUNE, T. M. \& SRAML GONZALEZ, J. 2019. The green flings: Norwegian oil and gas industry's engagement in offshore wind power. Energy Policy, 127, 269-279.

MÄKITIE, T., THUNE, T. M. \& SRAML GONZALEZ, J. 2018b. Chapter 13. From oil to wind, and back again: Resource redeployment and diversification. In: THUNE, T. M., ENGEN, O. A. \& WICKEN, O. (eds.) Petroleum Industry Transformations: Lessons from Norway and Beyond. Routledge.

NARAYANAN, V. K., YANG, Y. \& ZAHRA, S. A. 2009. Corporate venturing and value creation: A review and proposed framework. Research Policy, 38, 58-76.

NELSON, R. R. \& WINTER, S. G. 1982. An evolutionary theory of economic change, Cambridge, Mass, Belknap Press.

NEWELL, P. \& PATERSON, M. 1998. A Climate for Business: Global Warming, the State and Capital. Review of International Political Economy, 5, 679-703.

NORWEP 2017. Norwegian supply chain opportunities in offshore wind. Norwegian Energy Partners.

PARK, H. D. \& STEENSMA, H. K. 2012. When does corporate venture capital add value for new ventures? Strategic Management Journal, 33, 1-22.

PENNA, C. C. R. \& GEELS, F. W. 2015. Climate change and the slow reorientation of the American car industry (1979-2012): An application and extension of the Dialectic Issue LifeCycle (DILC) model. Research Policy, 44, 1029-1048.

PENROSE, E. 1959. The theory of the growth of the firm, Oxford, Blackwell.

PISANO, G. P. 2017. Toward a prescriptive theory of dynamic capabilities: connecting strategic choice, learning, and competition. Industrial and Corporate Change, 26, 747-762.

SAKHARTOV, A. V. \& FOLTA, T. B. 2015. Getting beyond relatedness as a driver of corporate value. Strategic Management Journal, 36, 1939-1959. 
SHARMA, P. \& CHRISMAN, J. J. 1999. Toward a Reconciliation of the Definitional Issues in the Field of Corporate Entrepreneurship. Entrepreneurship Theory and Practice, 23, 1128.

STEEN, M. \& WEAVER, T. 2017. Incumbents' diversification and cross-sectorial energy industry dynamics. Research Policy, 46, 1071-1086.

TANRIVERDI, H. \& VENKATRAMAN, N. 2005. Knowledge relatedness and the performance of multibusiness firms. Strategic Management Journal, 26, 97-119.

TEECE, D. J. 1982. Towards an economic theory of the multiproduct firm. Journal of Economic Behavior \& Organization, 3, 39-63.

TIDD, J. \& TAURINS, S. 1999. Learn or Leverage? Strategic Diversification and Organizational Learning Through Corporate Ventures. Creativity and Innovation Management, 8, 122-129.

TUSHMAN, M. L. \& O'REILLY, C. A. 1996. Ambidextrous Organizations: Managing Evolutionary and Revolutionary Change. California Management Review, 38, 8-29.

VAN MOSSEL, A., VAN RIJNSOEVER, F. J. \& HEKKERT, M. P. 2018. Navigators through the storm: A review of organization theories and the behavior of incumbent firms during transitions. Environmental Innovation and Societal Transitions, 26, 44-63.

WESSELING, J. H., NIESTEN, E. M. M. I., FABER, J. \& HEKKERT, M. P. 2015. Business Strategies of Incumbents in the Market for Electric Vehicles: Opportunities and Incentives for Sustainable Innovation. Business Strategy and the Environment, 24, 518-531.

ZAHRA, S. A. \& COVIN, J. G. 1995. Contextual influences on the corporate entrepreneurshipperformance relationship: A longitudinal analysis. Journal of Business Venturing, 10, 43-58. 